\title{
Role of Social Media Marketing in the Successful Implementation of Business Management
}

\author{
Saefudin Zuhdi, Anshar Daud, Rifki Hanif, Phong Thanh Nguyen, K. Shankar
}

\begin{abstract}
For increasing the sales, building the brands and driving the traffic of web to connect the people through platform of social media refers to as social media marketing. The social media marketing include running of social media advertisements, engaging followers, listening to followers, analyzing results and publishing content on social media profiles. Now in these days the major platforms of social media are Pinterest, Instagram, Snapchat, Twitter, Facebook, LinkedIn, YouTube and many more. These social media platform plays a major role for developing and increasing the business.

Keywords: social media, platform, business, advertisement, Facebook, YouTube
\end{abstract}

\section{INTRODUCTION}

For generating the traffic to their websites and contents of business shared on social media platform. The marketing of social media first begin with publishing. Just to broadcast the content is not only the work of social media marketing, it is far beyond this. The social media marketing use for sailing online.

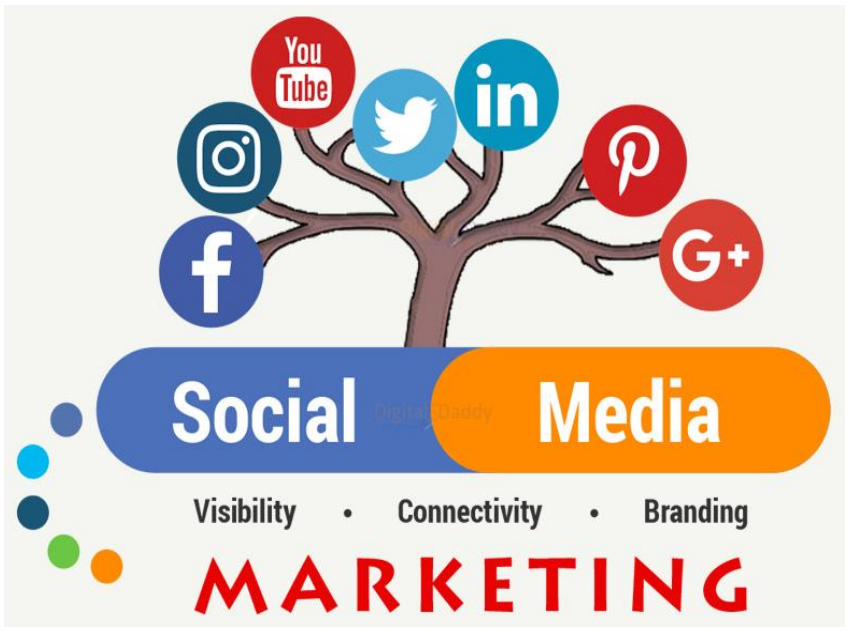

Figure 1: Social Media Marketing

Revised Version Manuscript Received on 16 September, 2019.

* Correspondence Author

Saefudin Zuhdi, Institut Bisnis dan Informatika Kesatuan, Indonesia. E-mail: saefudinzuhdi.kesatuan@gmail.com

Anshar Daud, STIE Nobel Indonesia, Makassar, Indonesia

Rifki Hanif, Sekolah Tinggi Ilmu Ekonomi Asia Malang, Indonesia

Phong Thanh Nguyen*, Department of Project Management, Ho Chi Minh City Open University, Vietnam. E-mail: phong.nt@ou.edu.vn

K. Shankar, Department of Computer Applications, Alagappa University, India. E-mail: shankarcrypto@gmail.com
SMO (Social media optimization is the significant element of SMM (social media marketing). For drawing unique and new visitors to a website like SEO (search engine optimization), Social media optimization strategy is used. In two ways it can use SMO: in first way by udating tweets and stauts, or posting a blog activity can be promoted. And in second way to the contents it add the links of social media like sharing buttons and RSS feeds.

\begin{tabular}{|c|c|c|}
\hline Business objective & Social media goal & \\
\hline Grow the brand & $\begin{array}{c}\text { Awareness (these metrics } \\
\text { illuminate your current and } \\
\text { potential audience) }\end{array}$ & Followers, shares, etc. \\
\hline $\begin{array}{c}\text { Turn customers into } \\
\text { advocates }\end{array}$ & $\begin{array}{c}\text { Engagement (these metrics } \\
\text { show how audiences are } \\
\text { interacting with your content) }\end{array}$ & $\begin{array}{c}\text { Comments, likes, } \\
\text { @mentions, etc. }\end{array}$ \\
\hline Drive leads and sales & $\begin{array}{c}\text { Conversions (these metrics } \\
\text { demonstrate the effectiveness } \\
\text { of your social engagement) } \\
\text { Consumer (these metrics } \\
\text { reflect how active customers } \\
\text { think and feel about your } \\
\text { brand) }\end{array}$ & $\begin{array}{c}\text { Testimonials, social media } \\
\text { sentiment, etc. }\end{array}$ \\
\hline $\begin{array}{c}\text { Improve customer } \\
\text { retention }\end{array}$ & \begin{tabular}{c} 
etc. \\
\hline
\end{tabular} &
\end{tabular}

Table 1: With Business Objective Goals of Social Media Marketing

\section{BUILDING THE STRATEGY OF SOCIAL MEDIA MARKETING}

with acheving the gaol the socail media mareketing startegy helps to tackle the brand. For identify the objective, optmize the result and enagane the viewers the socail medai marketing divided into following steps:

1. Setting the goals of social media marketing

2. Audience reasecrh

3. Most necessary metics establishment

4. Competiton analysis

5. Curate and create engaging content

6. Timeliness should be on top priority

7. Optimize and access the result

\section{The Core Pillars of Social Media Marketing}
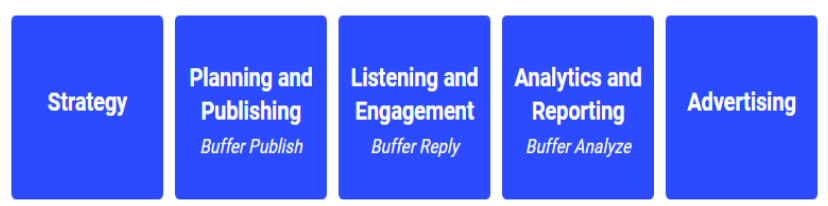

Figure 2: Core Pillars of Social Media Marketing 


\section{Strategy}

Before publishing any content on the social media, build the social media marketing strategy is the first step. The strategy of social media marketing includes:

a. Goals of social media marketing

b. The way in which social media help to achieve the goals of business

c. Use social media to increase brand awareness

d. Use social media for driving sales and website traffic

e. Defining the platform of social media. Many social media platforms are Twitter, Instagram, Facebook, YouTube, LinkedIn and many more are there.

f. Types of contents to be share

\section{Publishing and Planning}

Social media marketing for independent companies more often than not begins with having a predictable nearness via web-based networking media. By being available via web-based networking media stages, it offers brand a chance to be found by future clients.

\section{Engagement and Listing}

As the business and social media following develop, discussions about the brand will likewise increment. Individuals will remark on the online networking posts, tag in their online social networking posts, or message legitimately.

\section{Analytics}

En route, regardless of whether they are distributing content or connecting via web-based networking media, it will need to know how the web based life advertising is performing. It is safe to say that they are contacting a greater number of individuals via web-based networking media than a month ago? What number of positive notices does it get a month? What number of individuals utilized the brand's hash tag on their internet based life posts?

\section{Advertising}

When it has more assets to develop the Social media marketing, a zone that it can consider is internet based life publicizing. Social media marketing permit contacting a more extensive group of spectators than the individuals who are tailing it. Online life promoting stages are so incredible these days that it can determine precisely who to show advertisements to. It can make target spectators dependent on their socioeconomics, interests, practices, and then some

\section{SOCIAL MEDIA MARKETING FOR BUSINESSES}

Social media marketing promoting is an amazing route for organizations of all sizes to arrive at prospects and clients. The clients are as of now cooperating with brands through online social networking, and in case they're not talking legitimately to the group of spectators through social stages like Twitter, Instagram, Pinterest and Facebook, they're passing up a great opportunity! Incredible advertising via web-based networking media can carry astounding accomplishment to your business, making dedicated brand advocates and notwithstanding driving leads.
It can provide following goals:

1. Increasing awareness of brands

2. Website traffic increment

3. With key audience improve interaction and communication

4. Conversion building

5. Create Positive brand association and creating identity of brand

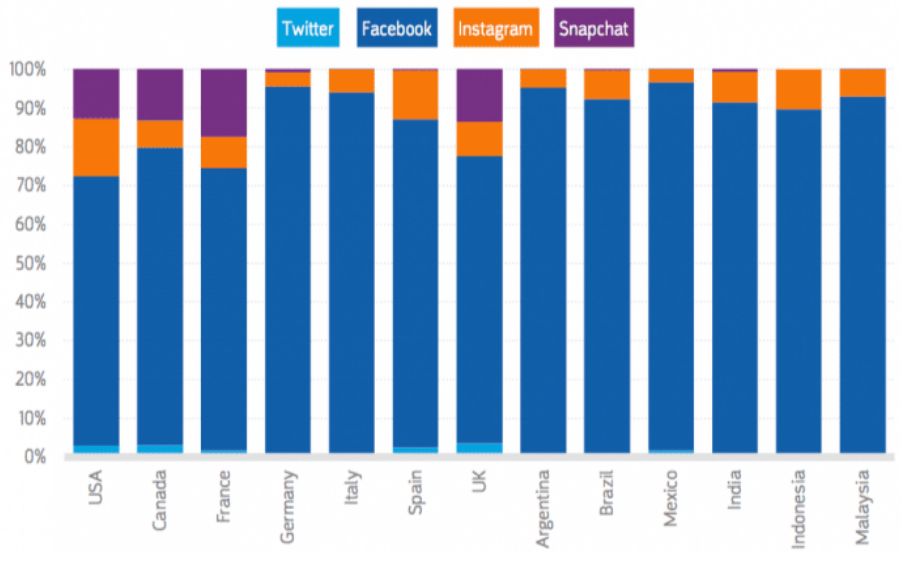

Figure 3: Social Media marketing global research

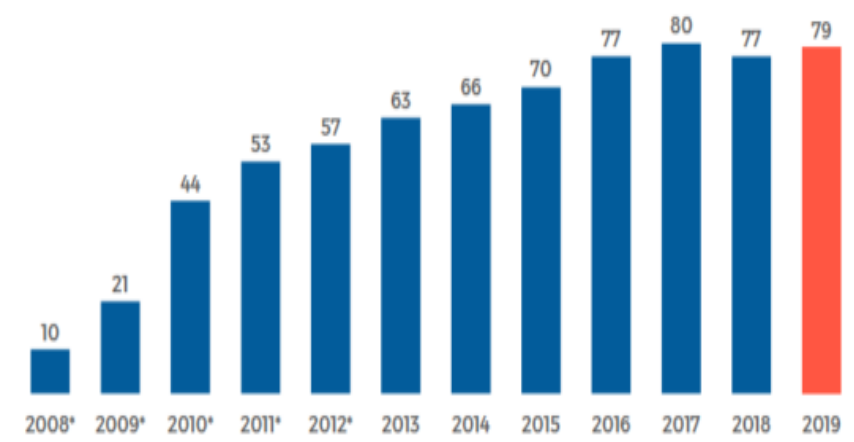

Figure 4: Social Meddia uses over the years

\section{The Advantages of Social Media Management}

There are numerous valid justifications to consider beginning an a social media management business. It'll be paid to utilize social media, which can be extraordinary if it's something as of now appreciate doing. Also, it requires little speculation or hardware to begin, particularly on the off chance that as of now have a computer and network access. It can maintain the business from home, or anyplace else with web get to.

\section{SOCIAL MEDIA FOR BUSINESS GROWTH}

A lot of internet based life action is brought out through cell phones. Ensure that your web based life methodology is good with cell phones to ensure an advantageous client experience. Online networking locales keep on picking up ubiquity at a quick rate and it is significant for little and developing organizations to utilize them to publicize and advertise what they offer. 


\section{In-house staff}

Social media software

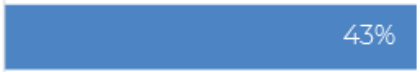

Digital marketing/social media agency

\section{$28 \%$}

Freelancer/consultant

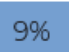

Figure 5: For business most resouces of social media marketing

\section{CONCLUSION}

Now in these days the major platforms of social media are Pinterest, Instagram, Snapchat, Twitter, Facebook, LinkedIn, YouTube and many more. These social media platform plays a major role for developing and increasing the business. For generating the traffic to their websites and contents of business shared on social media platform. The marketing of social media first begin with publishing. For increasing the sales, building the brands and driving the traffic of web to connect the people through platform of social media refers to as social media marketing.

\section{REFERENCES}

1. Akaka, M. A., Vargo, S. L., \& Lusch, R. F. (2012). An exploration of networks in value co-creation: A service ecosystems view. Review of Marketing Research, 9, 13-50.

2. Albors, J., Ramos, J. C., \& Hervas, J. L. (2008). New learning network paradigms: Communities of objectives, crowd-sourcing, wikis and open source. International Journal of Information Management, 28, 194-202.

3. Syazali, M., Putra, F., Rinaldi, A., Utami, L., Widayanti, Umam, R., \& Jermsittiparsert, K. 2019. "Partial Correlation Analysis Using Multiple Linear Regression: Impact on Business Environment of Digital Marketing Interest in the Era of Industrial Revolution 4.0." Management Science Letters 9 (11): 1875-1886.

4. Sae-Lim, P. \& Jermsittiparsert, K. 2019. "Is the Fourth Industrial Evidence in the Thai Economy." International Journal of Innovation, Creativity and Change 5 (2): 732-752.

5. Chatchawanchanchanakij, P., Arpornpisal, C., \& Jermsittiparsert, K. 2019. "The Role of Corporate Governance in Creating a Capable Supply Chain: A Case of Indonesian Tin Industry." International Journal of Supply Chain Management 8 (3): 854-864.

6. Hartinah, S., Suharso, P., Umam, R., Syazali, M., Lestari, B., Roslina, R., \& Jermsittiparsert, K. 2020. “Teacher's Performance Management: The Role of Principal's Leadership, Work Environment and Motivation in Tegal City, Indonesia." Management Science Letters 10 (1): 235-246.

7. Business.com. (2010, September 21). How B2B marketers are finding success integrating social media \& search marketing. Retrieved September 8, 2011.

8. Usak, M., Kubiatko, M., Shabbir, M., Dudnik, O., Jermsittiparsert, K., \& Rajabion, L. 2019. "Health Care Service Delivery Based on the Internet of Things: A Systematic and Comprehensive Study." International Journal of Communication Systems 32 (14): e4179.

9. Jermsittiparsert, K., Ambarita, D., Mihardjo, L., \& Ghani, E. 2019. "Risk-Return through Financial Ratios as Determinants of Stock Price: A Study from ASEAN Region." Journal of Security and Sustainability Issues 9 (1): 199-210. Revolution a Panacea? Risks toward the Fourth Industrial Revolution:

10. Thabhiranrak, T. \& Jermsittiparsert, K. 2019. "Towards Sustainable Functioning of Organization: Women Empowernment and Corporate Management Culture.” Journal of Security and Sustainability Issues 9 (1): 321-332.

11. Chienwattanasook, K. \& Jermsittiparsert, K. 2019. "Impact of Entrepreneur Education on Entrepreneurial Self-Employment: A Case Study from Thailand." Polish Journal of Management Studies 19 (1): 106-116.

12. Cohen, J. (2012, April 13). Supply your team with content to share on social media channels. Retrieved April 22, 2012.

13. De Vries, L., Gensler, S., \& Leeflang, P. S. H. (2012). Popularity of brand posts on brand fan pages: An investigation of the effects of social media marketing. Journal of Interactive Marketing, 26, 83-91.

14. Grunig, J., \& Grunig, L. (2001). The relationship between public relations and marketing in excellent organizations: Evidence from the IABC study. Journal of Marketing Communications, 4(3), 141-162.

15. Hays, S., Page, S. J., \& Buhalis, D. (2012). Social media as a destination marketing tool: Its use by national tourism organisations. Current Issues in Tourism,3500(May), 1-29.

16. Hogarth-Scott, S., Watson, K., \& Wilson, N. (1996).Do small businesses have to practice marketing to survive and grow? Marketing Intelligence\& Planning, 14(1), 6-18.

17. Jara, A. J., Parra, M. C., \& Skarmeta, A. F. (2014). Participative marketing: Extending social media marketing through the identification and interaction capabilities from the Internet of things. Personal and Ubiquitous Computing, 18,997-1011.

18. Chienwattanasook, K., Wattanapongphasuk, W., Prianto, A., \& Jermsittiparsert, K. 2019. "Corporate Entrepreneurship and Business Performance of Logistic Companies in Indonesia." Industrial Engineering \& Management Systems 18 (3): 538-547.

19. Dawabsheh, M., Hussein, A., \& Jermsittiparsert, K. 2019. "The Triangular Relationship between TQM, Organizational Excellence and Organizational Performance: A Case of Arab American University Palestine." Management Science Letters 9 (6): 921-932.

20. Jermsittiparsert, K., Siam, M., Issa, M., Ahmed, U., \& Pahi, M. 2019. "Do Consumers Expect Companies to Be Socially Responsible? The Impact of Corporate Social Responsibility on Buying Behavior.' Uncertain Supply Chain Management 7 (4): 741-752.

21. Haseeb, M., Hussain, H., Slusarczyk, B., \& Jermsittiparsert, K. 2019. "Industry 4.0: A Solution towards Technology Challenges of Sustainable Business Performance." Social Sciences 8 (5): 184.

22. Haseeb, M., Hussain, H., Kot, S., Androniceanu, A., \& Jermsittiparsert, K. 2019. "Role of Social and Technological Challenges in Achieving a Sustainable Competitive Advantage and Sustainable Business Performance.” Sustainability 11 (14): 3811.

23. Haseeb, M., Kot, S., Hussain, H., \& Jermsittiparsert, K. 2019. "Impact of Economic Growth, Environmental Pollution, and Energy Consumption on Health Expenditure and R and D Expenditure of ASEAN Countries.” Energies 12 (19): 3598.

24. Huda, S., Tsani, I., Syazali, M., Umam, R., \& Jermsittiparsert, K. 2020. "The Management of Educational System Using Three Law Auguste Comte: A Case of Islamic Schools." Management Science Letters 10 (3) (In press), DOI: 10.5267/j.msl.2019.9.018.

25. Kein “anen, H., \& Kuivalainen, O. (2015). Antecedents of social media B2B use in industrial marketing context: Customers' view. Journal of Business \& Industrial Marketing, 30, 711-722.

26. Mackey, T. K., \& Liang, B. A. (2013). Global reach of direct-to-consumer advertising using social media for illicit on-line drug sales. Journal of Medical Internet Research, 15,e105.

27. Mangold, W. G., \& Faulds, D. J. (2009). Social media: The new hybrid element of the promotion mix. Business Horizons, 52(4), 357-365.

28. Maseleno, A., Huda, M., Jasmi, K. A., Basiron, B., Mustari, I., Don, A. G., \& bin Ahmad, R. (2019). Hau-Kashyap approach for student's level of expertise. Egyptian Informatics Journal, 20(1), 27-32.

29. Jermsittiparsert, K., Sutduean, J., Sriyakul, T., \& Khumboon, R. 2019. "The Role of Customer Responsiveness in Improving the External Performance of an Agile Supply Chain." Polish Journal of Management Studies 19 (2): 206-217.

30. Jermsittiparsert, K., Sutduean, J., \& Sriyakul, T. 2019. "Effect of Service Innovation and Market Intelligence on Supply Chain Performance in Indonesian Fishing Industry.” Industrial Engineering \& Management Systems 18 (3): 408-417.

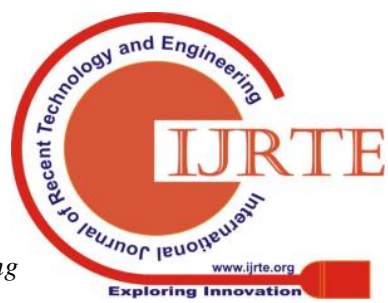


31. Jermsittiparsert, K., Namdej, P., \& Somjai, S. 2019. "Green Supply Chain Practices and Sustainable Performance: Moderating Role of Total Quality Management Practices in Electronic Industry of Thailand.” International Journal of Supply Chain Management 8 (3): 33-46.

32. Somjai, S. \& Jermsittiparsert, K. 2019. "The Trade-off between Cost and Environmental Performance in the Presence of Sustainable Supply Chain." International Journal of Supply Chain Management 8 (4): 237-247.

33. Jermsittiparsert, K. \& Sawasdee, A. 2012. "Formal Education for Non-Thai or Undocumented Person in Thailand amidst the Challenge of Nationalism and Transnationalism: A Case Study of Wa Sirimongkhol School, Samut Sakhon Province.” Kasetsart Journal Social Sciences 33 (2): 203-213.

34. Qazi, A., Raj, R. G., Tahir, M., Cambria, E., \& Syed, K. B. S.(2014). Enhancing business intelligence by means of suggestive reviews. Scientific World Journal, 2014, 879323.

35. Smith, A. N., Fischer, E., \& Yongjian, C. (2012). How does brand-related user-generated content differ across YouTube, Facebook, and Twitter? Journal of Interactive Marketing, 26, 102-113.

36. Tranfield, D., Denyer, D., \& Smart, P. (2003). Towards a methodology for developing evidence informed management knowledge by means of systematic review. British Journal of Management 14, 207-222.

37. Workman, A. D., \& Gupta, S. C. (2013). A plastic surgeon's guide to applying smart phone technology in patient care. Aesthetic Surgery Journal, 33, 275-280. 